\title{
Cremation a problem to African people
}

\author{
Maake J S Masango \\ Department of Practical Theology \\ University of Pretoria
}

\begin{abstract}
This article focuses on the issue of cremation the church is increasingly faced with and with which is has to deal. The issue has become very topical in South Africa as cemeteries are reaching capacity. Throughout its history the church, both Roman Catholic and Protestant, viewed cremation in a negative light. The author traces the reasons for this negativity back to the thirteenth century. Finally, the article focuses on relevant scriptural passages. South Africans can no longer avoid the issue because some cemeteries have already reached their full capacity and land for more cemeteries is limited.
\end{abstract}

\section{INTRODUCTION}

Harrison F quoted by Prothero introduces cremation by saying that:

\begin{abstract}
Cremation was the last baptism by incandescent heat, and the pure flame ascending to heaven was the symbol of the Holy Spirit. Their cause was the gospel of incineration, and its promotion missionary work.
\end{abstract}

(Prothero 2001:142)

The author is forced to ask this question, what then is cremation? Cremation is an ancient practice that has caused a lot of problems to the Church. Since the Second World War II in England the percentage of deaths in which cremation was employed to dispose of the body has risen from $7 \%$ to $46.9 \%$ (Irion 1968:1). In spite of this fact, a lot of people in South Africa still have the problem with cremation. Africans and Afrikaners seem to have more objections than English speaking South Africans. Why have African and Afrikaner people given little serious thought to this means for disposing of the bodies of the dead? There are different possibilities: It could be because of one resistance to major innovation in the sacred rituals and secular customs 


\section{Cremation a problem to African people}

surrounding death. The other reason could be the emotional reaction against the thought of burning the dead. The rapid destruction of the body or mental picture of the process could deter some persons from giving consideration to cremation. Africans and Afrikaners traditionally hold the view that the sacredness of the body belongs to God, and one does not tamper with God's creation. The other reason may be the popular understanding of the processes of preparing a dead body, which leads to the understanding that the body remains intact for a long period, and there is not then the same strong repugnance to the slower, but equally destructive, deterioration of the body in the grave.

Let me share a story that will help the reader understand the struggle of burning the body through cremation. It is the story of Mrs Mohaise (not the real name). Early in ministry I was confronted for the first time about the issue of cremation. One of our colleague minister's wife died. The husband started preparing for the cremation of the body. Mrs Mohaise's parents were members of my Church. They came to ask that I stop reverend Mohaise for proceeding with the cremation of their daughter's body. The other problem I faced when I visited him was that he was my senior by twenty years in the ministry. I was inexperienced but had to represent my members, and their problem to my own senior minister. The discussion was difficult. Finally he said to me, we (meaning his late wife and himself) decided on cremation years ago. He was ready to go ahead. The community was shocked; it was the first time a black person was going to be cremated in that township. Rumours were spreading and life was difficult during that time. The community expected a lot from me. The other problem we were facing was that we didn't have a liturgy for cremation in our denomination. The parents decided to go to court. It was a painful time for the parents, Church and community in Natalspruit. I had to support the parents. On the other hand I had to face the media, reporters made it worse in reporting about the matter. The whole procedure took two months before the court settled it. Mrs Mohaise was not buried until court finalized that she could be cremated. The ruling was that the husband had the right to follow their decision. The family broke down; people did not go to the memorial service (a service which is not popular in African townships). The family broke relationship with their son in law. My colleagues accused me of encouraging the parents to fight against him.

This is how I was introduced to the issue of cremation. In the seventies there were no pressing issues that compelled us to follow that practice. Today we are faced with graveyards that are full, and we need to do something.

South Africa is going through a difficult time due to HIV/Aids; lots of young people are dying. Some graveyards in Kwa-Zulu Natal, Alexandra and 
Soweto are full. The government is seriously considering cremation as the way of burial. I am aware of the resistance that is building up in African communities. The people are not ready to face cremation. The reader will understand why this topic is important, not only for South Africa, but also for students who are training for ministry. They need to be prepared for this new culture that is developing. The Church also needs to create a theology of cremation, as well as the liturgy for conducting that kind of service. Let us now analyze the struggles of the Church, especially how it dealt with this issue in the past.

\section{THE CHURCH}

The church has struggled with this problem since the thirteenth century. Ministers and theologians have resisted, and did not accept cremation, especially the Judeo-Christian faith groups. Even when officials ecclesiastical positions regarding cremation have been modified a, popular reluctance to support the practice has often continued. Although many of the commonly voiced reasons for religious opposition are not the teaching of any church or synagogue, the lay people often hold tenaciously to them.

The Roman Catholic Church in its position against cremation has followed closely against the stance of the early Church. The Church resisted the existing practice of cremation, especially in Europe; because it was practiced followed by non-Christians. The early Christians preferred burial to cremation, because of a desire to adhere to the customs followed in the burial of our Lord. Irion suggests that: "There was also popular sentiment against cremation, because it posed questions regarding the resurrection of the body; a germinal part of the Christian hope" (Irion 1968:74).

African people can also use the above quotation as the way of resisting cremation. Apart from a tampering with the temple (body) created by God, they also worry about resurrection. ${ }^{1}$ During heated debates about creation and burial in thirteenth century, the Roman Catholic Church ruled consistently in favour of the burial. ${ }^{2}$ Pope Bonifice VIII supported burial as normative practice, and threatened with excommunication anyone who engaged in process of disposition of the body through cremation, which circumvented natural deterioration. Research reveals that the custom of cremation grew out of the efforts to prepare bodies for shipment to distant homes from crusades times (Erickson 1908:6). Another interesting issue during this time was the

\footnotetext{
${ }^{1}$ During discussions I had with parents of Mrs Mohaise, they were worried about the resurrection of the body. They also asked, what they were going to do with the ashes.

${ }^{2}$ Pope Bonifice VIII, The modern crematist, vol IV, 4, 1889:504.
} 


\section{Cremation a problem to African people}

growing interest in the relics of the body of the saints. It has been suggested that this interest again supported burial as the normative means of disposing of the dead. Wilson and Levy had this to say about the above issue:

The superstition that sprang up relating to the miraculous value of the bodies and bones of the dead saints enhanced the value of skeletons. The stamp of priestly authority was given to earth burial, and the bones and bodies of the dead became associated with the religious beliefs of the age.

(Wilson \& Levy 1938:186)

It is interesting to note that the Roman Catholics Church's position was rarely enunciated officially until the rise of the modern cremation movement in the late nineteenth century. In 1880 cremation started in Italy - the Roman Catholic Church did not respond but was cooperative (Dorsett, D W H, 1908:482). Erichson reports that in 1887 the Roman Catholic priest did not opposed the practice of cremation, and had, in fact, in Lombardy accompanied the body to the crematorium for final prayers (Opcit 1908:486). These were the early responses. The problem rose when the congregation of propaganda formulated the official opposition before Erichson's publication in 1884:

No edict was issued by the councils of the early Church against the burning of the dead. It was not until 1884 that the congregation of propaganda issued a tentative opinion on the subject recommending passive disapproval - crematunem approbare non-debis, sed passive habeas.

(Wilson \& Levy 1938:186)

This passive approval was being practiced even though it was not official in Italy. The movement of popular mass resistance began from the people in local congregations. A similar experience can be expected in South Africa if the government continues to force legislation on cremation. The author's view is that Africans will bury people in back yards at night.

Pope Leo XIII issue several edicts after this movement against cremation started. Catholics were forbidden to join the cremation society. Catholics who resisted these decrees were to be denied burial by the Roman Catholic Church. ${ }^{3}$ Later on the decree added exclusion from receiving the last sacraments. Here are some of the canons that were issued at that time.

${ }^{3}$ Cremation and Canon Law, Pharos XXVII, Vol 1, 1961:3, 13. 
Canon 1203 states:

- $\quad$ The bodies of the faithful must be buried, their cremation is forbidden.

- If a person expresses a desire for cremation, it is forbidden to carry out this wish, if the desire is expressed in a statement or otherwise, it shall not be required as binding.

Canon 1240 states:

- $\quad$ Any one who has requested that his body be cremated; that person shall be deprived of ecclesiastical burial, unless he has shown signs of repentance before death.

- If there is any doubt in a case such as above, as time permits, the bishop should be consulted. If there is still any doubt, ecclesiastical burial should be accorded in order to prevent a scandal.

Canon 1241 states:

If there is any doubt in a case such as the above, and time permits, the bishop should be consulted. If there is still any doubt, ecclesiastical burial should be accorded to prevent a scandal.

Canon 1242 states:

Anyone who has been deprived of ecclesiastical burial will be deprived also of a requiem mass on the anniversary of his death and of all other funeral offices.

Canon 2339 states:

Anyone who seeks to obtain ecclesiastical burial for infides, apostates, heretics, schismatic or proscripts in accordance 1241 exposes himself to excommunication of the lower degree (which may be absoluted by the priest). If however he accords ecclesiastical burial to such, he will be subject to a prohibition to enter a Church, a punishment that may be suspended only by a bishop.

The above canon laws developed as a response to congregation's problems with cremation. People began to reject cremation as a form of burial. The Church is negative right up to today. Hence the Catholics will consecrate the 


\section{Cremation a problem to African people}

burial site as a way of affirming burial practices. The Catholic Church argued that, "Burial of the dead was not merely a sacred obligation. It was a God given right."

It is important to know that there was no reason given, for cremation has never been held to be in conflict with the dogma of that Church. In short, cremation became a matter related to Church discipline, just as the early Church resisted it as a pagan practice. When freemasons and agnostics followed this practice, it made matters worse. The Church took a stand that: "Cremation was cruel, barbarous, inhuman, dishonouring to the body ... and it was assumed as subverting the faithful" (Dorsett 1962:21)

The reason given for the above quotation or judgement is that cremation is contrary only to the laws of the Church, and not to dogma or divine law. Finally, it was not in keeping with the natural law. Thus people were prepared by the Church to be negative towards cremation. On the other hand, the critics of cremation argued again that cremation was wrong because it had a blasphemous intent. Prothero further said that: "Like the persecutors of the early Church, cremationist promoted their cause in order to show that they could conquer God, and destroy the resurrection of the bodies, saying, now let us see if they will rise" (Prothero 2001:79).

In other words, opponents of cremation were concerned that cremation would render less convincing the popular beliefs, behaviours, attitudes, and metaphors that created and sustained the credibility of the resurrection of the body, such as beliefs in the self as amalgamation of the body and the soul; fear of hell and fire; and prayers for the dead, cemetery visiting, and the metaphor of dead as sleep and body as temple. African people will probably support the above ideas of cremation. They will add that cremation is opposed to the sentiments of the thoughtful person who believes that human beings were created in the image and likeness of God. Therefore they say who are we? How can we dispose in such a way the body that has Gods' image? In other words, it encroached on the rights of creator, and anticipates the work of destruction, which belongs to God alone. Let us briefly analyze how protestant churches dealt with this matter.

\section{PROTESTANT CHURCHES}

The protestant brought no great change in the practice of burial. They did not make sweeping changes in the understanding of death, except the teaching about purgatory and intercessory prayers for the dead. The Scottish reformation became so anti-ritualistic that the corpse was inferred with no funeral service at all, but they did not depart from burying the dead. As the argument about cremation continued, the Scottish Church maintained burial 
as a proper way of disposing the body. Few of the English-speaking people started with practice of cremation. In 1885 the English cremation society performed its initial cremation service. The reaction of the church was not to offer any Christian prayers. Later a public hall was created in order to hold services apart from the church. The reasons for opposition to cremation were similar to those in the Catholic Church. The Scottish church social said in its declaration: "Cremation was a pagan custom and thus antithetical to the Christian practice" (Fraser 1965:25.)

It is clear that reformation churches opposed cremation because they could find no biblical warrant for it. Even though occasional mention is made of the practice in scriptures, as the ultimate rule of faith and practice, it offered no injunction to dispose of the dead by cremation. The Scottish Church finally supported burial because of the doctrine of resurrection which was presented as another good example. Frazer is helpful in explaining this concept further. He said: "Taking this concept very literally, some felt that if the body were burned, the resurrection would be prevented" (Frazer 1965:86).

The supporters of cremation pointed out that this was a misunderstanding of the doctrine of resurrection, because, they readily pointed it out in the words of St Paul: "Flesh and blood cannot inherit the Kingdom of God" (1 Cor 15:50). It was readily pointed out that dissolution by fire was faster but no more complete than dissolution in the grave. Heated debates were continued and people were confused and not guided by the church. The Rt Rev R W Stannared, dean of Rochester, was one of those who encouraged cremation. He said: "How important then from Christian stand point that the disposal of human remains should be attended with the greatest care and reverence, and there can be no clear and more beautiful method than that of cremation." (Jackson 1964:168).

One of the conservative white clergy (quoted in Jacson) arguing against cremation said:

The disposal of the body by cremation has in recent years been largely the choice of unbelievers and notorious characters. It is true that some good living people have requested it, but you will agree that the vast majority have been questionable characters. Such men requested cremation as Joseph Stalin, although in his case it was not carried out, Adolph Hitler, Y Vishinski, Adolf Eichmann, and nearly all of the notorious criminals of our day.

(Jackson 1965:25)

The reader will realize that there is no clear historical point at which opposition in the protestant Churches to cremation changed to acceptance. Some clergy 


\section{Cremation a problem to African people}

in 1910 were active and vocal supporters of the practice. As the protestant churches gradually became more liberal, there was wider acceptance of this mode of disposition among the whites. Throughout this research I became aware that the element of conservatism runs through out the history of the Church, especially in regard to cremation. The author is not surprised that the African side of the protestant churches is still continuing with conservative side of cremation. The African Church will continue to argue that there is no scriptural backing on cremation, hence burial. They will follow James Fraser's argument, which also says that there is no scriptural backing of cremation. The only time that I think that African people may agree at cremation is when a person had done atrocious deeds. Even then, they will finally opt for burial as a last resort - living God to judge the person. The Anglican Church completely dropped its early opposition. They took a position that cremation can only take place after a complete worship service with a coffin present in the Church. Another worship service will be held when disposing the ashes. Lastly, the Greek Orthodox Churches strongly opposes cremation. Today some Churches no longer base their arguments on theological ground. However, this issue is still a big problem among African Churches. In spite of the problem of cremation, Africans people need to face the issue of cremation because graveyards are getting full. This is one way in which we could solve the problem of graveyards. Another serious issue the African Churches need to face is the problem of availability of the land. Further question to ask is? Are the dead better than the living? Should they use up all the space for burial? These are difficult issue and the Churches must address them. The author is aware that it is going to be difficult to convince African people to opt for cremation, unless we have solid theological arguments to support our statements. The key question to ask is? What does the scriptures say about cremation? It is important to analyze the scripture concerning the issue of cremation as well as burial.

\section{CREMATION IN OLD TESTAMENT}

It is clear that both Jewish and Christian forms of disposal of the dead were that of earth burial, and not cremation. For example, the judgment upon Adam and Eve for their transgression indicates earth burial: "Dust thou art and unto dust thou shall return" (Gn 3:19).

It is interesting to note that Abraham the founder and the father of the Jewish race arranged for the burial of Sarah his wife in Genesis 15:12, 25, while Egypt, the persecutor of God's ancient people, practiced embalming. The reader need to be aware that African people will agree with Egypt's concept of embalming, because it honours the body as temple of God. They 
will prefer embalming and burial of the body rather than cremation. To them the body is the temple of the Holy Ghost. 1 Cor 3:16, 6:19. The Scriptures gives us the detailed account of the death and the burial of Moses in Deuteronomy 34:5 and chapter 6 . No one needs to ask, did the prohibition concerning fire, include the burning of the body? There are few passage of scriptures that are helpful in sharing this idea.

"And they go on building the high place of Topheth, which is the valley of the Son of Hinnom, to burn their sons and their daughters in the fire-which I did not command, nor did it come into my mind" (Jr 7:31)

The other passages where God condemns cremation as a practice, is found in the books of Lv 18:24 and 20: 1-4, and Ezk 23:27. The later reference suggest that cremation was associated with special judgment. The concept appears in a negative way and as a form of curse and judgment. The other concept of burial, which was practiced and quoted in the Scriptures, is embalming. Joseph, for example, was embalmed and buried. However, there are two places were cremation is mentioned without criticism, for example, Exodus 13:19 and Joshua 24:32. The continuation of fire appears again. For example, the bodies of Saul and his sons, so badly mingled, were burned before burial; "all the valiant man set out, travelled all night long, and took the body of Saul and the bodies of his sons from the wall of Beth-Shan. They came to Jabesh and burned them there" (1 Sm 31:12). Then they buried the ashes. "And they took their bones and buried them under the tamarisk tree in Jabesh, and fasted seven days" (1 Sm 31:13).

The other time when burning occurs, is at the time of war or plague. The book of Amos shows at length how this process is practiced. For example, "And if a relative, one who burns the dead, shall take up the body to bring it out of the house, and shall say to someone in the innermost parts of the house, 'is anyone else with you?' the answer will come, 'No'. Then the relative shall say, 'hush? We must not mention the name of the Lord'." Amos $6: 10$ refer to a burning of the man's kinsman, probably during the time when people were experiencing a plague. The "very great fire" of the burial of Asa' was not that of cremation, but a burning of spices and furniture in the king's honour: "They buried him in the tomb that he had hewn out for himself in the city of David. They laid him on a bier that had been filled with various kinds of spices prepared by the perfume's art, and they made a very great fire in his honour." (2 Chr 16:14.) On the other hand, Jeremiah also emphasizes the burning as well, by saying that: "you shall die in peace. And as spices were burned for your ancestors, the earlier kings who preceded you, so they shall burn spices for you and lament for you, saying 'alas, Lord' for I have spoken the word, says the Lord." (Jr 34:5.) 


\section{Cremation a problem to African people}

Another prophesies, against Jeroboam's false altar includes burning. In 1 Kings 13:1-3 it is simply a prophecy of a king who shall take the bones of those previously buried, and the priest of the high places that burn incense in false worship, and cause them to be burned on the false alter to further pollute it, and render it abominable. In conclusion: the Old Testament dealt with the issue of burning the dead, as a curse to those who were not faithful to God.

\section{CREMATION IN THE NEW TESTAMENT}

There is no actual reference to cremation in the New Testament. It is clearly evident that the early Christians followed up the Jewish custom of earth burial. John is helpful in reminding us of this practice: "They took the body of Jesus and wrapped it with the spices in linen clothes, according to the burial customs of the Jews" (Jn 19:20).

Jewish ritual however is silent in regard to specific methods of caring for the dead. When Paul spoke of giving his body to be burned, he was simply accommodating his language to the customs of Corinth. In his "magna carta of the resurrection", he speaks of the sowing of the body 1 Corinth 15:34-44. Other writers will use Jesus' burial as example. I find it a weak point to force the followers to follow suit. Using this New Testament passage of scripture as a point of reference for burial is not convincing. My argument is that, the corpse of Jesus was not buried in the hole on the ground, and covered over with a load of earth. He was buried in a rock-hewn vault prepared by wealthy Joseph of Arimathea for himself (Mt 27:57-61). In other words, the body of our Lord laid on a slab of stone. Furthermore I want to suggest that, it was necessary for Jesus to be buried thus, because it has been divinely decreed that he should rise on the third day without any corruption having taken place in his body. A good example is found in Psalms "For you do not give me up to Sheol, or let your faithful one see the pit" (Ps 16:10).

There other scripture is found in the book of Acts, which is sharing the above concept about Jesus. "For you will not abandon my soul to Hades, or let your Holy one experiencing corruption" (Ac 2:27). The other verse is found in verse 31. David spoke of the resurrection of the messiah saying: "He was not abandoned to Hades, nor died his flesh experiencing corruption" (Ac 2:31). The final verse says: "therefore he has also said in another Psalm, you will not let your holy one experience corruption" (Ac 13:35).

Does the above verse means that, if his body had remained another day in the tomb, corruption and decomposition would have set in, for according to Martha's description of her much-loved brother, Lazarus, she said: "he had been dead for four days and began to smell" (Jn 11:39). In other words, Jesus therefore came forth from the tomb with the very same body the disciples had washed, and perfumed with spices - uncontaminated by corruption or decay, and it is that very body, that is glorified, that he has in 
heaven, and which we are to behold with awe. As followers, we need to begin to develop methods that are healthy, so that we can continue to care for creation.

\section{CONCLUSION}

This research has proven to me that the stand of the church has influenced people to view cremation as negative part of disposing the body. As the result of the above, we need to embark on an educational process of helping people review cremation again. This process is to be embarked in three ways, 1) through research so that we have correct facts; 2) by educating and dialoguing with theological students 3 ) who will engage people or congregation in seminars, dialogue and sermons. We have a long way to go, but we need to start somewhere, Schuler quoted by Morris sums up this process better by saying that:

We should regard cremation as a much-needed reform, and as an essential public service, the most hygienic method. Cremation as an indoor service-safeguards the health of the mourner, whose health resistance may have been reduced by long periods of anxiety, and vigil at the sick bed. Cremation induces a more rational attitude to death by eliminating the grave and the morbid atmosphere of the cemetery.

(Morris 1956:80)

On the other hand Mitford likewise affirmed cremation by saying the following:

I heartily approve of cremation. In the first place it is cleanly, it helps along nature, and in the second place, it is economical. The body must eventually be turned to dust. Why not by cremation rather than have it decomposed in the ground.

(Mitford 1963:163)

A pastor that is faced with this issue, need to deal with it in a sensitive way. Facing the fact that cremation is making rapid strides in white English speaking South African communities, the minister may be constrained (especially African ones) to ask whether there is some spiritual issue at stake. $\mathrm{He} /$ she may personally shrink from the idea of cremation, yet feel that it is not right to object to it, even though he/she may oppose it - dialogue will be the first step that will make us analyze the issue with others. The author need to remind the reader that the Bible does not contain any judgment against the Greeks and Romans who practiced cremation in the same way as it warns against idolatry? Therefore, if modern crowded conditions make the 


\section{Cremation a problem to African people}

availability of ground for cemeteries increasingly difficulty, no Christian reason can be given against cremation as expediency. Time is coming or it has already arrived where we have to ask, are the dead better than the living? Can they continuing occupying land, while the living have no land to live upon? Did not Jesus say that God is able to raise children to Abraham out of the stones, and what is a stone, but a solidified dust? Therefore, whether we are against cremation when asked, we should respect the request and minister to those who are remaining by conducting the service. On the other hand if we are asked to conduct the burial likewise we should minister and care for the bereaved. The ultimate choice is between earth burial where nature takes a slow and painful cause of disintegration or the higher method of science by reducing dust to dust and ashes to ashes. My research led me to conclude that the manner of burial makes no difference whatever to the resurrection. The only problem is how we prepare our loved ones to grow into cremation with you. The actual burning of the body cannot bring any loss, otherwise the martyrs who suffered death by fire, and Christians burned to death accidentally or pulverized by any explosion, or eaten by wild animals or sharks at sea, could be in a state of inferiority. After death what happens to the body of the believer is of little consequence, it is the joy of resurrection that counts. The scriptures say: "He will transform the body of our humiliation that it may be conformed to the body of his glory, by the power that also enables him to make all things subject to himself" (Phlp 3:21).

Finally, Early of Shaftesbury quoted by Gorer says: "What will become of the blessed martyrs if the body cannot be returning to God in its original form by a wise and just God? The ashes of a saint are truly as venerable as his bones" (Gorer 1963:141).

Another researcher can spent time researching the above statement, so that he or she may help further explore the issue of burning or cremation. I am now convinced that: "Dust we are and unto dust all of us shall return." If the body is buried in the grave, the human body slowly disintegrates into basic molecules of which it is composed. Whether this breakdown occurs rapidly, as in cremation, or slowly as in an ordinary burial appears in material. We have to learn to think about the absent from the body and present with the Lord. God knows how he will gather the dust or ashes together when the miracles of resurrection take place. God, who is powerful, is able to resurrect bodies from buried dust or ashes. Let me finally ask this question, did not Jesus say that God is able to raise up Abraham's children out of the stones, and what is a stone but solidified dust. Therefore whether we are against cremation, when we are asked we should all respects the request and minister to those who are remaining by conducting a service. Once again, if we are asked to conduct a burial service, likewise we should minister and care for the bereaved. The ultimate choice then is between earth burial, where nature 
takes her slow process, or a higher method of science for reducing dust to dust, and ashes to ashes quickly. We therefore need to continue wrestling with these issues.

\section{Works consulted}

Dorsett, D W T 1962. The Roman Catholic attitude to cremation. Oxford: University Press.

Fraser, J W 1965. Cremation: Is it Christian? London: Nepture N J Loizeaux. Gorer, G 1963. Death, grief, and mourning. London: Cresset Press. Irion, P E 1968. Cremation. Philadelphia, PA: Fortress Press. Jackson, N E, 1964. For the living. New York: Channel Press. Jackson, N E 1957. Understanding grief. New York: Channel press.

Mitford, J 1963. The American way of the death. New York: Simon and Schuster. Prothero, S 2001. Purified by fire: A history of cremation in America. Berkley, CA: University of California Press.

Schuler, J 1956. The valley of silence. Grand Rapids, MI: Zondervan.

The Catholic encyclopedia V. 1908. s v Cremation, 481-833.

The encyclopedia Britannica $11^{\text {th }}$ ed, Vol Vii, 1911. s v Cremation, 403-406.

The encyclopedia Britannica $11^{\text {th }}$ ed, Vol VI, 1964. s v Cremation, 7221-22.

The Jewish encyclopedia, Vol IV, 1903. s v Cremation, 342-44.

Encyclopedia of Religion and Ethics, IV 1912:411-511, edited by J Hastings s v Death and disposal of death.

Pamphlets, published by The Free Presbyterian Church

Molder, J 1960. Advice concerning cremation as a part of Christian burial. Glasgow. Lerner, $\mathrm{H}$ 1963. Cremation the way of the nature. Glasgow: Education and Information Committee of the Cremation Association of America.

Samson, W 1965. Facts about cremation. Glasgow: Free Presbyterian Church Magazine.

Samson, W 1965. Why cremation? Glasgow: Free Presbyterian Church Magazine.

The Cremation society. A brief pamphlet promoting the use of cremation in England. 